\section{Acknowledgements}

The authors wish to thank Caroline Pryke, Cardiology, Addenbrooke's Hospital, Cambridge, for her contributions to this article. The authors also thank Dr S Nagaraju, Neuropathology, Queen Elizabeth Hospital, Birmingham; Dr J Cross, Neuroradiology, Addenbrooke's Hospital,; Dr E O'Brien, Medicine, Addenbrooke's Hospital; Dr B Seymour, Neurology, Addenbrooke's Hospital; and the Departments of Neuropathology, Cardiology and Medical Photography, Addenbrooke's Hospital.

\section{References}

1 Adams HP Jr, Bendixen BH, Kappelle LJ et al. Classification of subtype of acute ischemic stroke: definitions for use in a multicentre clinical trial. TOAST: Trial of Org 10172 in Acute Stroke Treatment. Stroke 1993;24:35-41.
2 Terracciano LM, Mhawech P, Suess K et al. Calretinin as a marker for cardiac myxoma. Diagnostic and histogenetic considerations. Am J Clin Pathol 2000;114:754-9.

3 Otto C. Textbook of clinical echocardiography, 4th edn. USA: Saunders Elsevier; 2009.

4 Lee VH, Connolly HM, Brown RD Jr. Central nervous system manifestations of cardiac myxoma. Arch Neurol 2007;64:1115-20.

5 Hanson EC, Gill CC, Razavi M, Loop FD. The surgical treatment of atrial myxomas. Clinical experience and late results in 33 patients. $J$ Thorac Cardiovasc Surg 1985;89:298-303.
Address for correspondence: Dr AW Pearce, Papworth Hospital NHS Foundation Trust, Papworth Everard, Cambridge CB23 3RE. Email: alex.pearce@papworth.nhs.uk

\title{
Literature and medicine
}

\section{Tomas Tranströmer's stroke of genius}

This column explores the links and synergies between medicine and literature. What roles can literature play in reflecting and influencing good practice, and what sorts of images of doctoring are to be found in drama, poetry, fiction, biography, electronic fora and film? The editors would be pleased to receive short papers, ranging from $500-1,000$ words, on relevant topics. Those interested in contributing should email brian. hurwitz@kcl.ac.uk or neil.vickers@kcl. ac.uk

In November 1990, the widely acclaimed Swedish poet Tomas Tranströmer (b. Stockholm, 1931) lost his speech and the use of his right hand as a result of a stroke. As if anticipating his own fate, in his longest poem Baltics (1974), he had referred to the story of a composer who became speechless and hemiplegic after a brain bleed:

Ivan Iniesta, consultant neurologist and honorary clinical lecturer

The Walton Centre NHS Foundation Trust and Liverpool University, UK
Then, cerebral hemorrhage: paralysis on the right side with aphasia,

can grasp only short phrases, says the wrong words.

Beyond the reach of eulogy or execration.

But the music's left, he goes on composing in his own style,

for the rest of his days he becomes a medical sensation.

He wrote music to texts he no longer understood

in the same way

we express something through our lives in the humming chorus full of mistaken words. ${ }^{1}$

Himself a lifelong amateur pianist, Tranströmer carried on playing the piano with his left hand after the stroke. Some pianists, inspired by his first post-stroke collection of verse, The sad gondola (1996), composed left-handed pieces for him, such as the Tranströmer settings for the New European Ensemble's 2010 tour of Sweden.

Left-handed piano pieces have been written by great composers, including Prokokiev and Richard Strauss. In 1928, Maurice Ravel composed The concerto for the left hand in B major for Paul Wittgenstein, the Austrian musician who had lost his right arm in the Great War, which enabled him to resume concert performances. Ten years later, in 1933, at the age of 58, the French composer came to the end of his musical career after losing his own speech through a brain insult that rendered him unable to express musical ideas in either writing or performance. $^{2}$

Neurology as a medical specialty was founded in the late $19^{\text {th }}$ century when disfunctioning structures of the brain were localised according to the anatomico-pathological method. A founding cornerstone of this approach was the 1861 structural localisation of expressive language, which was found to reside over the foot of the third left frontal convolution. This finding was confirmed by a brain necropsy on a patient of Paul Broca who had suffered from a 20 -year history of non-fluent aphasia. ${ }^{3}$ Since then, neurologists have recognised that almost all patients with expressive aphasia have some degree of difficulty in writing (dysgraphia). More challenging and overambitious are recent attempts to localise functions as complex and abstract as identification and appreciation of beauty and creativity by using cutting-edge brain-scanning technology. Such functions are not 'clean-cut. Like/ the shaved parts of a patient's crown before he has a brain operation' to borrow Tranströmer's expression referring to artificial landscapes. ${ }^{1}$

What makes Tranströmer a medical sensation - as prophetically announced in Baltics, the poem he regarded as his 'most consistent attempt to write music ${ }^{1}$ — is the fact that he managed to continue translating 
his ideas and images into words, creating language in the absence of speech, in poetry written in accordance with his own prophetic motto, 'language but no words, ${ }^{1}$ a phrase reminiscent of the physician-poet William Carlos Williams's motto, 'no ideas but in things' ${ }^{4}$

Williams also suffered a stroke aged also 59, after which he lost the use of his right hand (but not his speech). ${ }^{5}$ Some poems by Tranströmer, composed after the stroke, are concerned, like Williams's had been, with the limitations of spoken language. Tranströmer referred to:

The shaky-handed doctor' who 'wrote out a prescription that no one can/ decipher but his writing will be recognized...

Inasmuch as Williams's own medical practice influenced his poetry, Tranströmer's career as prison psychologist also became a source of his poetry. He was nevertheless surprised not to have been asked more often about how his poetry may have affected his work. ${ }^{6}$

In a letter to his friend and partial translator, Robert Bly, written before he suffered the stroke at the end of April of 1990, Tranströmer recalled a recent three-week holiday in Venice with his wife Monica. ${ }^{7}$ Interestingly, his first book after the stroke was inspired by Liszt's utterly depressing $L a$ lugubre gondola, which the Hungarian composer had written while visiting his daughter and son-in-law Richard Wagner. After the stroke, Transtromër's first lines were those of the poem, April in silence:
'I am carried in my shadow

like a violin

in its black case."

Before the stroke a non-prolific writer, after it Tranströmer became even more abbreviated in his writing, through what Seshadri called (in reference to aphasia) the 'inner weather of pure meaning. ${ }^{8}$ As the next anniversary of his Nobel Prize in literature approaches, we celebrate the translucent poetry of Tranströmer who, like Dostoevsky with his epilepsy ${ }^{9}$ and Williams with his stroke ${ }^{5}$ - all of whom were much helped by their wives - was able to transform suffering into art and through music and poetry overcome the great communication barriers imposed by aphasia.

In his post-stroke Like being a child a poetic lucidity is apparent:

'... and a sudden insult

is jerked over your head like a sack

through its mesh you catch a glimpse of the sun

and hear the cherry trees humming

No help in that - the great insult covers your head your torso your knees you can move sporadically

but can't look forward to spring

Glimmering woolly hat, pull it down over your face

stare through the stitches.

On the straits the water-rings are crowding soundlessly.

Green leaves are darkening the earth ....'
A rare living prophet in his own homeland, in Memories look at $m e^{1}$, Tranströmer produced some of the most illuminating autobiographical accounts ever written as well as poetry of the highest calibre, despite severe expressive dysphasia and dysgraphia.

\section{References}

1 Tranströmer T (translated by Robin Fulton). New collected poems. Glasgow: Bloodaxe Books, 2011.

2 Alajouanine T. Aphasia and artistic realization. Brain 1948;74:229-41.

3 Broca PP. Perte de la parole, ramollissement chronique et destruction partielle du lobe antérieur gauche. Bulletin de la Société d'Anthropologie 1861;2:235-8.

4 Williams WC. The collected poems of William Carlos Williams, 1909-1939 Vol. 1. New York: New Directions Publishing Corporation, 1991.

5 Iniesta I. The Iatroversalia (Doctor poems) of William Carlos Williams. Clin Med 2012;12:92-3.

6 Tranströmer T (translated by Robert Bly). The half-finished heaven. Minneapolis: Graywolf Press, 2001.

7 Tranströmer T, Bly R, Schmidt T, Svensson LH. Air mail: brev 1964-1990. Stockholm: Bonnier, 2001.

8 Seshadri V. Aphasia. The New Yorker; April 12 2004:42.

9 Iniesta I. On the good use of epilepsy by Fyodor Dostoevsky. Clin Med 2008;8:338-9.

Address for correspondence: Dr I Iniesta, The Walton Centre NHS Foundation Trust, Lower Lane, Fazakerley, Liverpool L9 7LJ. Email: ivan.iniesta@thewaltoncentre.nhs.uk 